\title{
Penentuan Harga Pokok Produksi dan Pendapatan Usahatani Kopi di Kecamatan Bulok Kabupaten Tanggamus
}

\author{
Determination of Production Cost and Coffee Farming Income in Bulok District, \\ Tanggamus Regency
}

\author{
Fembriarti Erry Prasmatiwi ${ }^{\star}$, Dyah Aring Hepiana Lestari ${ }^{1}$, R. Hanung Ismono ${ }^{1}$, Indah \\ Nurmayasari ${ }^{1}$, Rusdi Evizal ${ }^{2}$ \\ ${ }^{1}$ Jurusan Agribisnis Fakultas Pertanian Universitas Lampung, Bandar Lampung, 35141 \\ 2 Jurusan Agroteknologi Fakultas Pertanian Universitas Lampung, Bandar Lampung, 35141 \\ “Email: feprasmatiwi@yahoo.com dan fembriarti.erry@fp.unila.ac.id
}

Disubmit: 11 September 2019 Direvisi: 13 Desember 2019 Diterima: 10 Januari 2020

\begin{abstract}
Abstrak: Penentuan harga pokok produksi usahatani kopi diperlukan untuk menghindari kerugian bagi petani. Penentukan harga pokok produksi dapat membantu petani dalam mengambil keputusan untuk menjual atau melakukan tunda jual kopi jika harga jual berada di atas atau di bawah harga pokok produksi. Penelitian ini bertujuan untuk menghitung harga pokok produksi dan pendapatan usahatani kopi di Kecamatan Bulok Kabupaten Tanggamus. Penelitian menggunakan metode survei. Lokasi penelitian dilaksanakan di sentra produksi kopi Kecamatan Bulok yaitu Desa Napal dan Desa Pematang Nebak. Penelitian dilaksanakan pada bulan Januari-Maret 2019. Sampel dalam penelitian berjumlah 30 orang petani kopi yang diambil secara acak sederhana. Metode analisis yang digunakan adalah analisis deskriptif kuantitatif. Penentuan harga pokok produksi menggunakan metode variable costing. Hasil penelitian menunjukkan bahwa Harga Pokok Produksi usahatani kopi di Kecamatan Bulok Rp 13.598/kg. Harga ini lebih rendah dibandingkan harga jual. Usahatani kopi menguntungkan dengan R/C adalah 2,97 dan pendapatan petani adalah Rp11.407.951/hektar.
\end{abstract}

Kata kunci: biaya, kopi, pendapatan, produksi, usahatani

Abstract: Determination of production standard cost of coffee farming is important. Farmers can decide whether to sell their coffee immediately or to delay until the selling price is higher than the standard cost. This research is to calculate the standard cost of production and the income of coffee farming in Bulok Subdistrict of Tanggamus District of Lampung Province. This is a survey conducted in two villages as coffee production centers, namely Napal and Pematang Nebak. The study was conducted in January-March 2019.Samples were 30 coffee farmers taken simply randomly. Data are analyzed using a descriptive qualitative method. Production standard cost is determined using variable costing method. Results showed that coffee production standard cost in Bulok Subdistrict was Rp.13,598/kg which is lower than selling price. Coffee farming was profitable with $R / C$ value of 2.97 and the farming income was Rp.11,407.951/hektare.

Keywords: cost, coffee, farming, income, production 


\section{PENDAHULUAN}

Kopi merupakan komoditas perkebunan yang penting dan diperdagangkan di dunia. Empat negara penghasil kopi terbesar di dunia berturut-turut adalah Brazil, Vietnam, Kolombia, dan Indonesia. Volume dan nilai ekspor kopi Indonesia berfluktuasi namun cenderung meningkat. Pada tahun 2010 total volume ekspor kopi Indonesia mencapai 433,6 ribu ton dengan total nilai sebesar US\$ 814,3 juta meningkat menjadi 467,8 ribu ton pada tahun 2017 dengan total nilai sebesar US\$ 1 187,16 juta (BPS, 2017). Lima negara pengimpor kopi terbesar Indonesia adalah Amerika Serikat, Jerman, Malaysia, Itali, dan Rusia.

Mayoritas perkebunan kopi di Indonesia merupakan perkebunan rakyat. Data BPS (2017) menyatakan luas areal perkebunan kopi di Indonesia adalah 1.251.703 hektar dan 95,46\% perkebunan kopi diusahakan oleh perkebunan rakyat, 2,37\% diusahakan oleh perkebunan swasta, dan sisanya $2,17 \%$ dibudidayakan oleh perusahaan perkebunan negara. Produksi kopi Indonesia pada tahun 2017 adalah 666.992 ton (BPS, 2017). Lima provinsi produsen kopi terbesar di Indonesia adalah Sumatra Selatan, Lampung, Aceh, Sumatra Utara, dan Jawa Timur.

Lampung merupakan produsen kopi terbesar kedua di Indonesia. Luas areal perkebunan kopi di provinsi ini pada tahun 2017 adalah 161.416 hektar dengan produksi 116.346 ton dan produktivitas $831 \mathrm{~kg} / \mathrm{hektar}$ dan menyumbang produksi $17,40 \%$ dari total produksi kopi Indonesia. Keseluruhan perkebunan kopi di Lampung diusahakan oleh perkebunan rakyat dan melibatkan petani pekebun kopi 254.218 orang (BPS, 2017). Sekitar 99\% jenis kopi yang diusahakan petani Lampung merupakan jenis kopi robusta sisanya satu persen merupakan jenis kopi arabika (Direktorat Jenderal Perkebunan, 2015).

Kabupaten Tanggamus merupakan sentra perkebunan kopi di Provinsi Lampung dan menempati urutan kedua di provinsi ini setelah Kabupaten Lampung Barat. Luas areal kebun kopi di Tanggamus adalah 41.416 hektar dan produksi yang dicapai adalah 31.346 ton. Salah satu kecamatan penghasil kopi di Tanggamus adalah Bulok. Luas areal kopi di kecamatan ini adalah 1.198 hektar dan produksi yang dicapai adalah 680 ton dan tingkat produktivitas $568 \mathrm{~kg} /$ hektar (BPS, 2018).

Permasalahan yang dihadapi petani kopi di Kecamatan Bulok adalah rendahnya produktivitas kopi yaitu $568 \mathrm{~kg} /$ hektar lebih rendah dibanding rata-rata Provinsi Lampung yaitu $831 \mathrm{~kg} /$ hektar BPS (2018) dan harga jual kopi yang berfluktuasi karena fluktuasi produksi yang diakibatkan oleh pengaruh cuaca dan iklim (Hartatri dan Rosari, 2011). Hal ini menyebabkan pendapatan petani rendah. Harga jual kopi di tingkat petani sangat terkait dengan harga kopi di pasaran internasional. Harga kopi yang diterima petani kopi di Lampung sangat dipengaruhi pasar kopi global (Hutabarat, 2006). Jika dibandingkan dengan pihak-pihak yang terlibat dalam tata niaga kopi maka petani kopi menempati posisi yang paling lemah dan paling besar menerima risiko kerugian.

Sebagai seorang produsen, petani kopi akan berorientasi untuk menghasilkan laba dan dapat mengembalikan seluruh biaya atau modal yang telah dikeluarkan. Jika ada perubahan harga kopi, petani tidak bisa secepatnya menyesuaikan biaya produksi yang dikeluarkan. Untuk itu penentuan harga pokok produksi sangat diperlukan bagi petani. Dengan menentukan harga pokok produksi maka dapat membantu petani dalam mengambil keputusan waktu untuk menjual kopi apakah akan menjual atau menahan kopi jika harga jual sedang di atas atau di bawah harga 
pokok produksi. Tujuan penelitian ini adalah untuk menghitung harga pokok produksi dan pendapatan petani kopi di Kecamatan Bulok Kabupaten Tanggamus.

\section{METODE PENELITIAN}

Penelitian menggunakan metode survei. Lokasi penelitian dipilih secara sengaja di dua sentra produksi kopi di Kecamatan Bulok dan terpilih Desa Napal dan Desa Pematang Nebak. Sampel dalam penelitian berjumlah 30 petani kopi yang diambil secara acak sederhana. Penelitian menggunakan data primer dan sekunder. Data primer didapatkan dengan survei dan wawancara terstruktur dengan petani kopi menggunakan kuesioner yang telah dipersiapkan. Data sekunder diperoleh melalui studi literatur, penelusuran pustaka, atau publikasi lainnya serta dari instansi terkait. Pengambilan data penelitian dilaksanakan pada bulan Januari-Maret 2019.

\section{Harga Pokok Produksi (HPP)}

HPP merupakan keseluruhan biaya produksi yang terserap ke dalam setiap unit produk yang di hasilkan perusahaan. Penentuan harga pokok produksi dapat di lakukan dengan metode variable costing dan full costing (Mulyadi, 2010). Penentuan HPP dalam penelitian ini menggunakan metode variable costing. Penentuan HPP berdasar metode variable costing hanya memperhitungkan biaya produksi variabel. Biaya yang dimasukkan dalam perhitungan adalah biaya bahan baku, upah tenaga kerja langsung, dan biaya produksi lainnya (biaya overhead). Penentuan HPP kopi dalam penelitian ini dengan memperhitungkan ketiga macam biaya tersebut.

Kopi merupakan tanaman tahunan yang mulai berproduksi pada umur 3 tahun dengan produksi yang masih kecil. Pada umur 4 tahun produksi mulai meningkat (Prasmatiwi et al. 2010). Seperti pada tanaman keras lainnya, biaya produksi dibedakan menjadi dua yaitu biaya investasi (establishment costs). dan biaya operasional untuk berproduksi tiap tahun (annual cost). Biaya investasi adalah keseluruhan biaya yang dikeluarkan sejak persiapan lahan, penanaman, pemeliharaan sampai dengan tanaman mulai berbuah atau menghasilkan. Dalam hal ini biaya investasi usahatani kopi adalah biaya yang dikeluarkan pada tahun pertama sampai ketiga karena pada tahun keempat tanaman kopi baru menghasilkan.

Biaya investasi cukup dikeluarkan hanya satu kali, namun hasilnya dapat dinikmati sepanjang tahun sampai umur ekonomis kopi habis yaitu berkisar 25 tahun atau dengan kata lain biaya yang dikeluarkan selama 3 tahun akan digunakan untuk berproduksi selama 22 tahun. Dengan demikian, biaya investasi ini akan dibebankan pada tiap-tiap tahun selama kopi berproduksi. Pembebanan biaya investasi per tahun digunakan rumus (Nirwanto, 2011):

$$
\mathrm{X}=\frac{S}{n}
$$

$\mathrm{X}=$ Pembebanan biaya investasi per tahun (biaya investasi $\mathrm{u}$ )

$\mathrm{s}=$ Total Biaya investasi

$\mathrm{n}=$ Jumlah tahun (22 tahun)

Biaya produksi untuk operasional tiap tahun $(\mathrm{Y})$ dikeluarkan tiap tahun sejak kopi mulai berbuah. Komponen biaya operasional tiap tahun dapat dikelompokkan menjadi tiga yaitu biaya bahan baku, upah tenaga kerja langsung, dan biaya overhead. Upah tenaga kerja langsung merupakan keseluruhan upah yang 
dikeluarkan untuk membayar tenaga kerja misalnya membayar tenaga kerja penyiangan, pemupukan, panen, penjemuran, pengendalian hama penyakit dan lainlain. Biaya bahan baku adalah keseluruhan biaya untuk pembelian pupuk dan pestisida. Termasuk biaya overhead adalah biaya angkut kopi, biaya karung, biaya tali dan lain-lain.

Dengan demikian total biaya tiap tahun dapat dihitung dengan rumus.

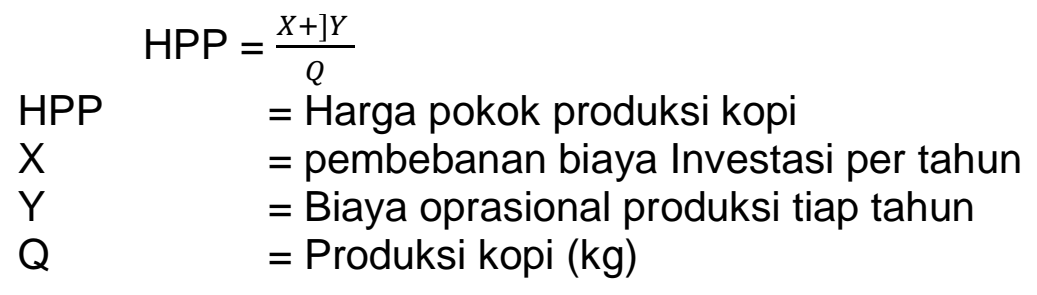

HPP merupakan biaya atau harga pokok produksi pada saat menghasilkan produksi satu $\mathrm{kg}$ kopi pada tahun yang bersangkutan. Dengan semakin besarnya produksi kopi maka HPP akan semakin kecil.

\section{Pendapatan Usahatani Kopi}

Pendapatan merupakan selisih dari penerimaan dengan biaya yang dikeluarkan. Penerimaan dari usahatani kopi berasal dari penerimaan dari biji kopi serta dari tanaman naungan maupun tanaman yang ditumpangsarikan dalam kebun kopi tersebut. Untuk menghitung pendapatan usahatani kopi sebagai berikut (Soekartawi, 2018).

$$
\begin{aligned}
\pi & =\text { TR }-T C \\
& =(Q \times P)-(T F C+T V C)
\end{aligned}
$$

$$
\begin{array}{ll}
\text { Keterangan } \\
\pi \quad=\text { Pendapatan }(\mathrm{Rp}) \\
\text { TR } \quad=\text { Total revenue atau penerimaan }(\mathrm{Rp}) \\
\text { TC } \quad \text { Total cost atau total biaya }(\mathrm{Rp}) \\
\mathrm{Q} \quad=\text { Produksi yang dihasilkan }(\mathrm{Kg}) \\
\mathrm{P} & =\text { Harga jual kopi }(\mathrm{Rp} / \mathrm{kg}) \\
\text { TVC } & =\text { Total biaya variabel }(\mathrm{Rp}) \\
\text { TFC } & =\text { Total biaya tetap }(\mathrm{Rp})
\end{array}
$$

\section{HASIL DAN PEMBAHASAN}

\section{Profil Responden}

Petani kopi di Kecamatan Bulok tergolong dalam usia produktif yaitu berumur antara 41 sampai 58 tahun dengan rata-rata usia 50 tahun. Pendidikan petani mayoritas tamat SMP yaitu sebesar $50 \%$ diikuti tamat SD sebesar $36,57 \%$ tamat SD dan sisanya $13,33 \%$ adalah tamatan SMA. Jumlah anggota keluarga berkisar 2 sampai 5 orang. Usahatani kopi merupakan pekerjaan utama petani dan sebesar $83,33 \%$ menjadikan usahatani kopi satu-satunya sumber pendapatan dalam rumah tangganya dan sisanya hanya $16,67 \%$ yang mempunyai pekerjaan sampingan selain berusahatani kopi.

Luas lahan usahatani kopi berkisar antara 1 sampai 4 hektar dengan rata-rata luas lahan kopi garapan petani adalah 2 hektar. Keseluruhan petani mengusahakan 
kopi di lahan sendiri atau status lahannya merupakan hak milik. Pengalaman usahatani antara 2 sampai 25 tahun dengan rata-rata pengalaman petani adalah 13 tahun. Umur kopi yang diusahatkan petani bervariasi. Paling muda berumur 2 tahun dan paling tua berumur 25 tahun. Rata-rata umur kopi adalah 13 tahun. Jarak tanam kopi yang diusahakan petani bervariasi mayoritas $2,5 \times 2,5 \mathrm{~m} ; 2,5 \times 2 \mathrm{~m}$; dan $2 \times 2$ $\mathrm{m}$ sehingga jumlah tanaman kopi per hektar bervariasi sebesar 1.600, 2.000, dan 2.500 tanaman kopi per hektar.

\section{Penentuan Harga Pokok Produksi (HPP)}

HPP akan berpengaruh terhadap keuntungan maupun kerugian suatu usaha. HPP adalah seluruh biaya yang dikeluarkan untuk mengolah bahan baku menjadi hasil produksi pada periode tertentu. Dengan demikian HPP usahatani kopi adalah keseluruhan biaya yang dikeluarkan petani untuk menghasilkan produksi kopi. Seperti halnya tanaman tahunan yang lain, biaya usahatani kopi dapat dibedakan menjadi biaya investasi dan biaya produksi tahunan. Menurut Prasmatiwi et al (2010), biaya investasi merupakan biaya yang dikeluarkan sebelum tanaman kopi menghasilkan, Biaya investasi dikeluarkan dari pengolahan lahan sampai dengan tahun ketiga. Komponennya meliputi biaya untuk persiapan lahan, pengolahan lahan, penanaman kopi, penanaman naungan, serta biaya pemeliharaan kopi. Biaya operasional tahunan merupakan keseluruhan biaya produksi tahunan setelah tanaman kopi menghasilkan yaitu biaya untuk pemupukan, pembelian pestisida, pembayaran tenaga kerja dan lain-lain. Biaya investasi usahatani kopi di Kecamatan Bulok disajikan pada Tabel 1.

Tabel 1. Biaya investasi usahatani kopi di Kecamatan Bulok Tanggamus (Rp/hektar)

\begin{tabular}{cccc}
\hline Jenis Biaya & \multicolumn{3}{c}{ Biaya pada umur tanaman kopi } \\
\cline { 2 - 4 } & I & II & III \\
\hline a. Bibit & 1.510 .501 & 0 & 0 \\
b.Pupuk & & & 750.000 \\
- Kandang & 750.000 & 750.000 & 342.126 \\
- Urea & 202.130 & 342.126 & 324.325 \\
- NPK & 144.426 & 324.325 & 280.558 \\
- TSP & 180.556 & 280.558 & 280.320 \\
- SP36 & 165.625 & 280.320 & \\
c. Pestisida & & & 119.224 \\
- Sidolaris & 101.212 & 119.224 & 71.833 \\
- Round up & 71.833 & 71.833 & 65.000 \\
- Gramaxone & 65.000 & 65.000 & 4.539 .675 \\
d. Tng kerja & 7.539 .675 & 4.539 .675 & \\
e. Lain-lain & & & 250.000 \\
- Transport & 450.000 & 250.000 & 48.825 \\
- Lain-lain & 48.825 & 48.825 & 7.071 .886 \\
\hline Total Biaya & 11.229 .783 & 7.071 .886 & \\
\hline
\end{tabular}

Pada tahun pertama biaya usahatani kopi paling tinggi. Hal ini dapat dipahami bahwa pada tahun pertama petani kopi mengeluarkan biaya untuk pembelian bibit serta upah tenaga kerja pembukaan dan pengolahan lahan yang jumlahnya besar. Dari Tabel 1 dapat dihitung biaya investasi usahatani kopi yaitu penjumlahan biaya tahun pertama, kedua, dan ketiga yaitu Rp 25.373.555/hektar. Biaya investasi tersebut dibebankan untuk usahatani kopi sampai umur ekonomis habis atau 
selama 22 tahun kopi berproduksi. Jadi biaya per tahun adalah Rp1.153.343,43/hektar/tahun.

Pada tahun keempat, tanaman kopi memasuki masa menghasilkan (TM). Pada umumnya petani di Kecamatan Bulok dalam mengelola usahatani kopi pada saat tanaman menghasilkan adalah sama. Komponen biaya produksi untuk operasional tahunan usahatani kopi adalah hampir sama seperti pada tahun kedua dan ketiga, namun pada saat TM ditambah biaya panen, penjemuran, dan transportasi hasil panen dari kebun ke rumah serta transportasi untuk menjual kopi.

Dalam penentuan HPP kopi, maka biaya dibedakan menjadi tiga yaitu biaya tenaga kerja, biaya bahan baku, dan biaya overhead. Untuk itu dalam menentukan HPP kopi, maka biaya dibedakan menjadi tiga jenis yaitu biaya tenaga kerja, biaya bahan baku, dan biaya overhead. Biaya tenaga kerja merupakan keseluruhan biaya untuk membayar tenaga kerja baik tenaga kerja dalam keluarga maupun luar keluarga untuk kegiatan pemeliharaan kebun meliputi pemupukan, penyiangan, dan pengendalian hama, penyakit, dan gulma serta panen dan pasca panen.

Biaya bahan baku merupakan biaya untuk pembelian pupuk dan pestisida, sedang biaya overhead merupakan biaya untuk pembelian karung, tali, dan transportasi hasil panen maupun sarana produksi.

Tabel 2. Biaya produksi tanaman menghasilkan (TM) usahatani kopi di Kecamatan Bulok Tanggamus (Rp/hektar/tahun)

\begin{tabular}{cc}
\hline Komponen biaya & Jumlah biaya (Rp/hektar) \\
\hline I. Biaya Tenaga kerja & 5.509 .675 \\
II. Biaya Bahan Baku & \\
Pupuk Kandang & 750.000 \\
Urea & 342.126 \\
NPK & 324.325 \\
TSP & 280.558 \\
Sp36 & 280.320 \\
Round up & 119.224 \\
Gramaxone & 71.833 \\
III Biaya Overhead & 65.000 \\
Transportasi/ojek & \\
lain-lain: karung, tali & 503.000 \\
IV. Total Biaya TM & 92.325 \\
\hline
\end{tabular}

Biaya produksi usahatani kopi pada saat tanaman menghasilkan (TM) adalah Rp8.338.386/hektar/tahun (Tabel 2). Biaya terbesar (66,07\%) dikeluarkan untuk membayar tenaga kerja.

Total biaya usahatani kopi untuk menghasilkan produksi kopi tiap tahun merupakan penjumlahan dari pembebanan biaya investasi per tahun ditambah biaya produksi tahunan yaitu sebesar Rp9.491.729/hektar/tahun. Dengan produksi kopi rata-rata yang dihasilkan petani pada tahun 2014 sd 2018 seperti pada Tabel 3. Maka harga pokok produksi HPP kopi dapat ditentukan. HPP kopi tertinggi dicapai pada tahun 2017 yaitu Rp16.565, pada tahun tersebut produksi kopi rendah yaitu $573 \mathrm{~kg} / \mathrm{h}$ ektar. Sebaliknya HPP terendah dicapai pada tahun 2015 yaitu Rp11.718 pada saat produksi $810 \mathrm{~kg} /$ hektar.

Petani tidak dapat menentukan harga jual kopi. Harga jual kopi di tingkat petani tidak dapat dipisahkan dari harga kopi pasar internasional (Hutabarat, 2006). Jika harga jual kopi di atas HPP maka petani mendapatkan keuntungan. Jika harga jual 
kopi di atas HPP, maka petani dapat menjual kopinya. Sebaliknya jika harga jual di bawah HPP, maka petani harus menunda penjualan kopinya untuk menghindari kerugian.

Tabel 3. HPP usahatani kopi di Kecamatan Bulok Tanggamus tahun 2014-2018.

\begin{tabular}{cccccc}
\hline \multirow{2}{*}{ Keterangan } & \multicolumn{5}{c}{ Tahun } \\
\cline { 2 - 6 } & $\mathbf{2 0 1 4}$ & $\mathbf{2 0 1 5}$ & $\mathbf{2 0 1 6}$ & $\mathbf{2 0 1 7}$ & $\mathbf{2 0 1 8}$ \\
\hline Produksi kopi (kg/hektar) & 629 & 810 & 797 & 573 & 698 \\
Biaya investasi per & 1.153 .343 & 1.153 .343 & 1.153 .343 & 1.153 .343 & 1.153 .343 \\
tahun(Rp) & 8.338 .386 & 8.338 .386 & 8.338 .386 & 8.338 .386 & 8.338 .386 \\
Biaya produksi TM (Rp) & 9.491 .729 & 9.491 .729 & 9.491 .729 & 9.491 .729 & 9.491 .729 \\
Total Biaya (Rp) & 15.090 & 11.718 & 11.909 & 16.565 & 13.598 \\
HPP kopi (Rp/kg) & & & & & \\
\hline
\end{tabular}

Pendapatan usahatani kopi

penelitian ini menghitung pendapatan usahatani kopi satu tahun terakhir yaitu tahun 2018. penerimaan usahatani kopi diperoleh dari produksi kopi dan hasil dari tanaman naungan dan tanaman tumpangsari di kebun kopi. produksi kopi yang dihasilkan petani pada tahun 2018 adalah $698 \mathrm{~kg} / \mathrm{hektar}$.

Tabel 4. Analisis pendapatan usahatani kopi per hektar di Kecamatan Bulok Kabupaten Tanggamus

\begin{tabular}{|c|c|c|c|c|c|}
\hline & Keterangan & Satuan & Jumlah fisik & Harga(Rp) & Nilai (Rp) \\
\hline \multirow[t]{3}{*}{1} & Penerimaan & & & & \\
\hline & Produksi kopi & $\mathrm{Rp}$ & 698,00 & 19.840 & 13.848 .320 \\
\hline & $\begin{array}{l}\text { Penerimaan tumpang } \\
\text { sari }\end{array}$ & $\mathrm{Rp}$ & & & 3.936 .539 \\
\hline
\end{tabular}

2 Biaya Produksi

\begin{tabular}{|c|c|c|c|c|}
\hline a. Biaya Tunai & & & & \\
\hline - Pupuk Kandang & $\mathrm{kg}$ & 750,00 & 1.000 & 750.000 \\
\hline - Urea & $\mathrm{kg}$ & 136,85 & 2.500 & 342.126 \\
\hline - NPK & $\mathrm{kg}$ & 108,11 & 3.000 & 324.325 \\
\hline - TSP & $\mathrm{kg}$ & 112,22 & 2.500 & 280.558 \\
\hline - SP36 & $\mathrm{kg}$ & 93,44 & 3.000 & 280.320 \\
\hline - Sidolaris & liter & 3,41 & 35.000 & 119.224 \\
\hline - Round up & liter & 1,20 & 60.000 & 71.833 \\
\hline - Gramaxone & liter & 1,08 & 60.000 & 65.000 \\
\hline $\begin{array}{l}\text {-Tenaga kerja luar } \\
\text { (TKLK) }\end{array}$ & HOK & 75,89 & 50.000 & 3.794 .500 \\
\hline - Pajak & $\mathrm{Rp}$ & & & 26.578 \\
\hline - karung, tali dll & $\mathrm{Rp}$ & & & 92.325 \\
\hline - Biaya angkut & $\mathrm{Rp}$ & & & 230.119 \\
\hline $\begin{array}{l}\text { - Total biaya tunai } \\
\text { b. Biava Diperhitunakan }\end{array}$ & $\mathrm{Rp}$ & & & 6.376.908 \\
\hline - Biaya transportasi & $\mathrm{Rp}$ & & & 272.881 \\
\hline - Sewa lahan & $\mathrm{Rp}$ & & & 2.000 .000 \\
\hline $\begin{array}{l}\text { - Penyusutan } \\
\text { - T.keria dlm keluarga }\end{array}$ & $\mathrm{Rp}$ & & & 48.825 \\
\hline$(T K D K)$ & HOK & 34,3 & 50.000 & 1.715 .000 \\
\hline $\begin{array}{l}\text { Total biaya } \\
\text { diperhitungkan }\end{array}$ & $\mathrm{Rp}$ & & & 4.036.706 \\
\hline Total biaya & $\mathrm{Rp}$ & & & 10.413 .614 \\
\hline
\end{tabular}




\begin{tabular}{|c|c|c|c|}
\hline 3 & $\begin{array}{l}\text { a. Pendapatan atas biaya } \\
\text { tunai }\end{array}$ & $\mathrm{Rp}$ & 11.407 .951 \\
\hline & $\begin{array}{l}\text { b. Pendapatan atas biaya } \\
\text { total }\end{array}$ & $\mathrm{Rp}$ & 7.371 .245 \\
\hline 4 & $\begin{array}{l}\text { a. } \mathrm{R} / \mathrm{C} \text { atas biaya tunai } \\
\text { b. } \mathrm{R} / \mathrm{C} \text { atas biaya total }\end{array}$ & & $\begin{array}{l}2,79 \\
1,71\end{array}$ \\
\hline
\end{tabular}

Produksi tersebut lebih rendah jika dibandingkan hasil penelitian di Sumowono Jawa Tengah yang dapat mencapai $1.617 \mathrm{~kg} / \mathrm{hektar}$ Isyariansyah, Sumarjono dan Budiraharjo (2018), di Bengkulu yaitu 976,19 kg/hektar Listyati et al (2017) dan di Sumbawa yaitu $900 \mathrm{~kg} /$ hektar (Aklimawati, Yusianto dan Mawardi, 2014). Petani menjual kopi dalam bentuk kopi biji (kopi beras) ke tengkulak yang datang ke desa dengan rerata harga jual kopi biji adalah Rp19.840/kg. Dengan demikian penerimaan dari kopi sebesar Rp13.848.320.

Di Kecamatan Bulok, tanaman tumpangsari kopi yang paling banyak dibudidayakan adalah pisang, petai, durian dan lada yang dipanjatkan pada tanaman naungan kopi. Penerimaan dari tumpangsari di kebun kopi adalah Rp3.936.539/hektar/tahun atau menyumbang $22,13 \%$ dari penerimaan lahan kopi. Penelitian Evizal et al (2014) menyatakan tanaman naungan kopi merupakan variabel penting yang menentukan produktivitas dan keberlanjutan usahatani kopi di Lampung Barat, Penelitian Prasmatiwi (2011) menemukan bahwa pohon naungan kopi memberikan tambahan penerimaan pada petani. Petani memperoleh tambahan penerimaan dari lada yang ditanam memanjat pada tanaman naungan gliriside. produksi tanaman naungannya sepert durian, alpokat, kapuk, kemiri, pinang, petai, dan jengkol

Pendapatan usahatani kopi merupakan selisih dari penerimaan dengan biaya. Biaya usahatani dibedakan menjadi dua yaitu biaya tunai serta biaya yang diperhitungkan seperti disajikan pada Tabel 4. Biaya tunai yang dikeluarkan petani kopi di Kecamatan Bulok adalah Rp6.376.908/hektar sedang biaya total usahatani kopi adalah Rp10.413.614/hektar. Dengan demikian pendapatan usahatani kopi atas biaya tunai adalah Rp11.407.951/hektar dan pendapatan atas biaya total adalah Rp 7.371.245/hektar. Hasil tersebut sejalan dengan penelitian Wahyuni, Utama dan Mulyasar (2012) di Bengkulu dan Hartatri dan Rosari (2011) di Kabupaten Manggarai dan Manggarai Timur bahwa usahatani kopi menguntungkan.

Pendapatan usahatani kopi yang positif sejalan dengan nilai Return-Cost Ratio atau $\mathrm{R} / \mathrm{C}>1$. Pada Tabel 4 dapat dicermati bahwa $\mathrm{R} / \mathrm{C}$ usahatani kopi atas biaya tunai 2,79 dan R/C atas biaya total adalah 1,79 . R/C merupakan nisbah antara penerimaan dengan biaya. Dengan nilai R/C yang lebih besar 1 maka usahatani kopi di Kecamatan Bulok menguntungkan. Penelitian Sari, Sutiarso dan Hadi (2018) di Bondowoso menyatakan bahwa Penggunaan biaya produksi pada usahatani kopi sudah efisien, dengan nilai R/C sebesar 1,85. Petani lahan luas lebih efisien dibanding petani lahan sempit. Menurut Audry dan Djuwendah (2018) semakin luas lahan usaha petani semakin tinggi biaya produksi yang dikeluarkan dan semakin tinggi pula pendapatan yang diterima. Nilai R/C atas biaya tunai usahatani kopi di Kecamatan Bulok adalah 2,79 mengandung makna bahwa setiap satu rupiah biaya tunai yang dikeluarkan dalam usahatani kopi akan menghasilkan penerimaan sebesar 2,79. Nilai $\mathrm{R} / \mathrm{C}$ atas biaya total adalah 1,71 yang berarti setiap satu rupiah biaya total yang dikeluarkan akan menghasilkan penerimaan sebesar 1,71 rupiah. 


\section{SIMPULAN}

Harga Pokok Produksi kopi di tingkat petani di Kecamatan Bulok Kabupaten Tanggamus yang dihitung dengan pendekatan variabel costing pada tahun 2018 adalah Rp 13.598/kg. HPP kopi berada di bawah harga jual kopi. Petani tidak dapat menentukan harga jual kopi. Jika harga jual kopi di atas HPP, maka petani dapat menjual kopinya. Sebaliknya jika harga jual di bawah HPP, maka petani harus menunda penjualan kopinya. Usahatani kopi di Kecamatan Bulok menguntungkan. Pendapatan usahatani kopi atas biaya tunai adalah Rp11.407.951/hektar dan pendapatan atas biaya total adalah Rp 7.371.245/hektar. R/C usahatani kopi atas biaya tunai 2,79 dan $\mathrm{R} / \mathrm{C}$ atas biaya total adalah 1,79

\section{DAFTAR PUSTAKA}

Aklimawati, L., Yusianto dan S. Mawardi. 2014. Karakteristik Mutu dan Agribisnis Kopi Robusta di Lereng Gunung Tambora, Sumbawa. Pelita Perkebunan 30(2): 159-180.

Audry, R. J dan E. Djuwendah. 2018. Analisis Pendapatan Usahatani Kopi Java Preanger pada Kelompok Tani Margamulya Desa Margamulya Kecamatan Pengalengan Bandung. Jurnal IImu Pertanian dan Peternakan 6(1): 31-38.

Badan Pusat Statistik (BPS). 2017. Statistik Kopi Indonesia.

Badan Pusat Statistik (BPS) Provinsi Lampung (2018). 2018. Provinsi Lampung dalam Angka.

Direktorat Jenderal Perkebunan. 2015. Statistik Perkebunan Indonesia 2014-2016. Kementerian Pertanian.

Evizal, R., Sugiatno., F.E. Prasmatiwi and I. Nurmayasari. 2016. Shade Tree Species Diversity and Coffee Productivity in Sumberjaya, West Lampung, Indonesia". Biodiversitas 17(1): 234-240.

Hartatri, D.F.S dan B. Rosari. 2011. Analisis Usahatani dan Rantai Pemasaran Kopi Arabika di Kabupaten Manggarai dan Manggarai Timur. Pelita Perkebunan 27(1): 55-67.

Hutabarat, B. 2006. Analisis Saling Pengaruh Harga Kopi Indonesia dan Dunia. Jurnal Agronomi Ekonomi 24(1): 21-40.

Isyariansyah, M.D., D. Sumarjono dan K. Budiraharjo. 2018. Analisis Faktor-Faktor Produksi yang Mempengaruhi Produksi Kopi Robusta di Kecamatan Sumowono Kabupaten Semarang. Agrisocionomics 2(1): 31-38.

Listyati, D., B. Sudjarmoko., A.M. Hasibuan dan E. Randriani. 2017. Analisis Usaha Tani dan Rantai Tata Niaga Kopi Robusta di Bengkulu. Jurnal Tanaman Industri dan Penyegar J.TIDP 4(3): 145-154.

Mulyadi. 2010. Akuntansi Biaya. Unit Penerbit dan Percetakan Sekolah Tinggi IImu Manajemen YKPN Yogyakarta.

Nirwanto, R. 2011. Analisis Penentuan Harga Pokok Produksi Kopi pada Tingkat Petani Kopi di Kecamatan Kembang Kabupaten Bondowoso. Skripsi. Jurusan S1 Akuntansi Fakultas Ekonomi Universitas Jember.

Prasmatiwi, F.E., Irham, A. Suryantini dan Jamhari. 2010. Analisis Keberlanjutan Usahatani Kopi di Kawasan Hutan Kabupaten Lampung Barat dengan pendekatan nilai ekonomi lingkungan". Pelita Perkebunan 26: 57-69. 
Sari, E.I., E. Sutiarso dan S. Hadi. 2018. Analisis Keuntungan dan Efisiensi Penggunaan Biaya Usahatani Kopi Rakyat Robusta Di Kecamatan Sumber Wringin Kabupaten Bondowoso. Jurnal Agribest 2(1): 61-69.

Soekartawi. 2018. Analisis Usahatani. Universitas Indonesia Press, Jakarta.

Prasmatiwi, F.E. 2011. Penerapan Konservasi dan Pengaruhnya terhadap

Produktivitas Usaha Tani Kopi di Kabupaten Lampung Barat. Prosiding Seminar Hasil Penelitian \& Pengabdian Kepada Masyarakat Unila. 167-175.

Wahyuni, S.S., S.P. Utama dan G. Mulyasar. 2012. Analisis Kelayakan Finansial Usahatani Kopi Arabika Di Desa Bandung Baru Kecamatan Kabawetan Kabupaten Kepahiang. Agrisep 11(1): $43-50$. 